\title{
DIVERSIFIKASI PENGOLAHAN TELUR AYAM RAS DENGAN METODE PENGGARAMAN UNTUK PENGUATAN EKONOMI MASYARAKAT DI DESA JATIPAMOR
}

\author{
Dini Widianingrum*, Dede Salim Nahdi, Dadang Sudirno \\ Universitas Majalengka \\ *diniwidianingrum@unma.ac.id
}

\begin{abstract}
Eggs are a good source of animal protein for the community, cheap in price, and easy to obtain. The complete nutritional content of eggs can increase endurance so as to create a good immune system. In addition, it is also to strengthen the community's economy during this pandemic and new habit. Many people have lost their jobs because their mobility is limited. So the need for new products of good quality, easy to process, affordable prices, and easy to market, including salted eggs. Generally salted eggs from duck eggs, but for diversification of egg processing can also be from chicken eggs. The diversification of chicken egg processing coupled with the promotion of the digital era is hoped that the people of Jatipamor Village, Panyingkiran District, Majalengka Regency, are healthy and strong economically in the new habit. The purpose of this activity is to obtain good quality salted chicken eggs so that they can be consumed and marketed properly. The extension method was carried out by means of lectures, discussions, and demonstration plots with PKK cadres, the community, and MSMEs in Jatipamor Village for 20 days. Monitoring and evaluation is carried out with continuous coaching. The results of the activity showed that the quality of the salted eggs produced by broilers was very good and worthy to be marketed with the following characteristics: clean and smooth egg shell, fresh aroma, no fishy smell, savory taste, and salty. In conclusion, participants understand and can practice processing salted chicken eggs well.
\end{abstract}

Keywords: chicken salted egg; economic booster

\begin{abstract}
Abstrak
Telur merupakan makanan sumber protein hewani yang baik bagi masyarakat, murah harganya, dan mudah diperoleh. Kandungan nutrisi telur yang lengkap dapat meningkatkan daya tahan tubuh sehingga tercipta daya tahan tubuh yang baik. Selain itu juga untuk penguatan ekonomi masyarakat di masa pandemic dan masa kebiasaan baru ini. Masyarakat banyak yang kehilangan pekerjaan karena mobilitasnya dibatasi. Sehingga perlunya produk baru yang berkualitas baik, mudah diolah, harga terjangkau, dan mudah dipasarkan antara lain telur asin. Umumnya telur asin dari telur itik, namun untuk diversivikasi pengolahan telur juga bisa dari telur ayam ras. Diversifikasi pengolahan telur ayam ras ditambah dengan promosi era digital ini diharapkan masyarakat Desa Jatipamor Kecamatan Panyingkiran Kabupaten Majalengka sehat badan dan kuat ekonomi di masa kebiasaan baru. Tujuan kegiatan ini yaitu untuk memperoleh kualitas telur asin ayam ras yang baik sehingga dapat dikonsumsi dan dipasarkan dengan baik. Metode penyuluhan dilakukan dengan cara ceramah, diskusi, dan demplot dengan peserta kader PKK, masyarakat, dan UMKM di Desa Jatipamor selama 20 hari. Monitoring evaluasi dilakukan dengan pembinaan yang berkesinambungan. Hasil kegiatan menunjukkan bahwa kualitas telur asin ayam ras yang dihasilkan sangat baik dan layak untuk dipasarkan dengan ciri-ciri sebagai berikut kerabang telur bersih dan halus, aroma segar tidak bau amis, rasanya gurih, dan masir. Kesimpulannya peserta memahami dan dapat mempraktekkan pengolahan telur asin ayam ras dengan baik.
\end{abstract}

Kata Kunci: telur asin ayam ras; penguat ekonomi

\begin{tabular}{l|l|l} 
Submitted: $2021-09-18$ & Revised: $2021-10-18$ & Accepted: $2021-10-26$
\end{tabular}

\section{Pendahuluan}

Telur merupakan salah satu bahan pangan yang paling lengkap gizinya (Kunaifi et al., 2019). Selain itu, bahan pangan ini juga bersifat serba guna karena dapat dimanfaatkan untuk berbagai keperluan. Telur adalah substansi yang dihasilkan oleh ternak itu sendiri di dalam tubuhnya, substansi tersebut membentuk organisme baru atau kehidupan baru. Selain dibungkus dengan kulit yang keras sebagai pelindung, telur juga dilengkapi dengan bahan makanan yang lengkap (Suci et al., 2020). 
Komposisi telur terdiri dari protein $13 \%$, lemak $12 \%$, serta beberapa vitamin dan mineral. Kuning telur mengandung asam amino esensial yang dibutuhkan serta mineral, seperti zat besi, fosfor, sedikit kalsium, dan vitamin B kompleks (Ariviani et al., 2019). Sebagian protein (50\%) dan semua lemak terdapat pada kuning telur. Adapun putih telur, yang jumlahnya sekitar 60 persen dari seluruh bulatan telur, mengandung 5 jenis protein dan sedikit karbohidrat. Sumber protein bisa berasal dari protein nabati dan protein hewani. Salah satu sumber protein hewani yang penting bagi manusia disamping daging dan ikan adalah telur. Telur banyak dikonsumsi oleh masyarakat umum karena mudah didapat dan harganya terjangkau dibandingkan daging dan ikan (Jazil et al., 2013).

Telur asin adalah salah satu bentuk pengawetan telur yang menggunakan metode penggaraman. Telur asin dapat ditemukan di beberapa negara, misalnya Indonesia, Cina dan Taiwan (Novia et al., 2018). Keuntungan dari proses pengasinan disamping pengawetan adalah meningkatkan cita rasa, yaitu masir atau berpasir yang didapatkan dari kuning telur. Telur yang biasa digunakan untuk pembuatan telur asin adalah telur bebek. Hal ini adalah karena telur bebek mempunyai kadar lemak yang lebih tinggi dibandingkan dengan telur ayam (Qonita et al., 2019).

Telur asin dapat dibuat dengan cara merendam menggunakan media garam. Garam berfungsi sebagai pencipta rasa asin sekaligus sebagai bahan pengawet karena garam mampu menyerap air dari dalam telur (Ramli \& Wahab, 2020). Garam akan masuk kedalam telur melalui pori-pori kulit telur menuju ke putih telur, lalu ke kuning telur. Garam akan menarik air yang dikandung telur. Garam juga terdapat ion klor yang berperan sebagai penghambat pertumbuhan bakteri dalam telur, sehingga menyebabkan telur menjadi awet karena bakteri yang terkandung dalam telur mati (Asiah, 2021).

Tujuan dari kegiatan ini yaitu memberikan penyuluhan dan pelatihan kepada kader PKK, masyarakat, dan UMKM untuk diversifikasi pengolahan telur ayam ras menggunakan metode penggaraman agar mendapatkan produk berupa telur asin yang menyehatkan masyarakat serta laku dan layak untuk dijual, sehingga meningkatkan imun dan menjadi penguat ekonomi masyarakat di masa pandemic serta adaptasi kebiasaan baru.

\section{Metode}

Metode Pelaksanaan kegiatan ini dilakukan dengan cara mengkoordinasikan terlebih dahulu dengan Kepala Desa Jatipamor terkait teknis dimana akan dilaksanakan kegiatan pelatihan ini. Kegiatan dilakukan di balai Desa Jatipamor Kecamatan Panyingkiran Kabupaten Majalengka. Sebelum penyuluhan dilaksanakan, dilakukan Pre-Test kepada masyarakat sebagai peserta penyuluhan terlebih dahulu. Setelah itu, dilakukan penyuluhan dengan metoda ceramah tentang potensi telur ayam ras, kondisi pandemik, dan materi mengenai pengolahan telur ayam ras menggunakan metode penggaraman agar mendapatkan produk berupa telur asin yang menyehatkan masyarakat serta laku dan layak untuk dijual, sehingga meningkatkan imun dan menjadi penguat ekonomi masyarakat di masa pandemic serta adaptasi kebiasaan baru. Kemudian dilakukan demonstrasi cara serta diskusi mengenai telur asin dan kegiatan diakhiri dengan PostTest.

Pengolahan telur ayam ras dengan metode penggaraman sesuai petunjuk (Qomaruddin \& Afandi, 2017):

1. Bahan antara lain $6 \mathrm{~kg}$ telur ayam ras, $4 \mathrm{~kg}$ garam krosok, $3 \mathrm{~kg}$ abu, 6 liter air, jeruk 3 buah nipis, dan $100 \mathrm{~g}$ cabe rawit diiris tipis. Alat yang digunakan antara lain 3 buah baskom plastic besar, ampelas, 5 buah egg tray, panic, kompor, sinduk, 2 buah toples plastic besar, 25 pcs mika, dan label atau merk.

2. Prosedur pembuatan dengan 2 media yaitu yang pertama media air dan abu gosok. Pembuatan media air yaitu memasak 6 liter air sampai mendidih, memasukkan $2 \mathrm{~kg}$ garam 
krosok, lalu dinginkan, memasukkan jeruk nipis dan cabe rawit. Mengampelas dan membersihkan telur dengan air dan alcohol. Memasukkan telur ke dalam toples, usahakan telur terendam oleh larutan air garam. Apabila telur mengambang bisa diberi pemberat seperti plastic air. Menutup rapat toples agar udara tidak masuk, sehingga proses penetrasi garam ke dalam telur secara anaerob selama 14 hari. Pembuatan media abu gosok yaitu campurkan $3 \mathrm{~kg}$ abu gosok dan $2 \mathrm{~kg}$ garam krosok, lalu memasukkan air secukupnya sampai media abu bisa dibentuk. Membalut telur satu persatu dengan media abu sampai tertutup rapat, lalu memasukkannya ke dalam toples, membiarkan toples terbuka diangin-angin sampai 14 hari. Hari ke-15 pengasinan telur sudah selesai. Proses pemanenan telur asin yaitu membersihkan dan merebus telur, lalu didinginkan. Koreksi rasa dan telur asin ayam ras siap kemas dengan mika yang telah diberi label.

\section{Hasil dan Pembahasan}

1. Kegiatan Penyuluhan, diskusi, dan Demplot

Diversifikasi pengolahan telur ayam ras menggunakan metode penggaraman diawali dengan pembukaan dan sambutan Kepala Desa Jatipamor yang menyambut baik adanya kegiatan ini, dilanjutkan dengan harapan agar masyarakat terutama kader PKK dan UMKM dapat benar-benar mengerti, memahami, dan dapat melaksanakan pengolahan telur ayam ras menjadi telur asin ini dengan baik.

Tujuan dari kegiatan ini yaitu memberikan penyuluhan dan pelatihan kepada kader PKK, masyarakat, dan UMKM untuk diversifikasi pengolahan telur ayam ras menggunakan metode penggaraman agar mendapatkan produk berupa telur asin yang menyehatkan masyarakat serta laku dan layak untuk dijual, sehingga meningkatkan imun dan menjadi penguat ekonomi masyarakat di masa pandemic serta adaptasi kebiasaan baru.

Peserta penyuluhan dengan tekun menyimak ceramah yang disampaikan, kemudian bertanya apabila ada hal yang belum jelas, mempraktekan proses pembuatan telur asin ayam ras. Pembinaan dilakukan secara berkesinambungan sampai saatnya panen peserta sangat antusias memanen telur asin, melihat warnanya, mencoba rasanya, mencium aromanya, dan meraba teksturnya. Hasilnya peserta penyuluhan mendapatkan telur asin ayam ras yang mempunyai kualitas baik. Berdasarkan uji organoleptic terhadap warna, aroma, rasa, dan tekstur telur asin ayam ras kepada peserta ternyata mereka sangat menyukainya. Hal ini dapat disebabkan resep pengolahan dan metode penggaraman yang baik, proses pengasinan dilakukan dengan baik, bahan yang digunakan mempunyai kualitas yang baik pula, dan pembinaan yang dilakukan dengan baik dan benar terutama metode penggasinannya.

Pengasinan merupakan salah satu upaya untuk mengawetkan telur ayam ras, mengurangi bau amis dan menciptakan rasa khas. Proses pengasinan telur yang umum dilakukan oleh masyarakat dengan menggunakan garam dapur sebagai bahan pengawetnya. Garam merupakan faktor utama dalam proses pengasinan telur yang berfungsi sebagai bahan pengawet untuk mencegah pembusukan telur, sehingga meningkatkan daya simpannya (Novia dkk, 2011:70).

Pengasinan telur dapat dilakukan dengan merendam telur dalam larutan garam jenuh (metode basah) dan dengan membalut/membungkus telur dengan adonan garam, dan abu (metode kering) (Putri, 2019). Kedua metode pengasinan mempunyai kelebihan masing-masing. Metode basah memiliki kemampuan penetrasi garam ke dalam telur berlangsung lebih cepat akan tetapi albumin telur relatif lebih basah. Sebaliknya metode kering penetrasi garam lebih lambat dan albumin telur lebih padat. Berdasarkan perbedaan metode pengasinan metode kering lebih disukai oleh panelis (Engelen, 2017).

Pada umumnya garam yang digunakan masyarakat adalah garam Natrium klorida ( $\mathrm{NaCl} /$ garam dapur) (Qomaruddin \& Afandi, 2017). Penambahan garam pada pengawetan berpengaruh terhadap protein telur. Penambahan garam yang berlebihan dapat mengakibatkan protein mengalami denaturasi. Protein yang ada di dalam telur mengalami denaturasi disebabkan 
adanya perubahan pada struktur sekunder dan tersier akibat terjadinya interaksi dengan garam (Asiah, 2021). Protein yang terdenaturasi berkurang kelarutannya, akibatnya protein akan terpisah sebagai endapan. Denaturasi protein yang dipengaruhi konsentrasi garam berpengaruh pada kadar protein (Budiman \& Rukmiasih, 2007).

Sifat fisik telur asin yang diamati umumnya adalah tingkat kemasiran kuning telur. Telur asin ayam ras menghasilkan kemasiran kuning telur sebesar 92,8\% sedangkan telur asin itik menghasilkan kemasiran kuning telur sebesar 93,3\%. Tekstur masir ini terjadi karena garam masuk bersama air ke dalam granul-granul yang berada dalam kuning telur (Faridah, 2017). Garam tersebut akan merusak ikatan LDL (Low Dencity Lipoprotein) sebagai penyusun terbesar granul. Kerusakan ikatan LDL (Low Dencity Lipoprotein) ini akan memperbesar diameter dari granula. Semakin sedikit air yang masuk dalam granul maka batas antara granul dalam kuning telur semakin tampak (Bao et al., 2021).

Tingkat kesukaan berdasarkan uji organoleptic antara lain warna, aroma, rasa, dan tekstur. Telur asin ayam ras dan telur asin itik adalah berbeda nyata artinya telur asin ayam lebih disukai dari pada telur asin itik dari segi warna (Qomaruddin \& Afandi, 2017). Hal ini disebabkan karena warna pada kuning telur asin ayam berwarna orange cerah lebih menarik dibandingkan dengan telur asin itik yang warna kuning telurnya hitam kehijauan sehingga panelis lebih menyukai telur asin itik dibandingkan telur asin ayam. Warna kuning telur yang baik adalah kuning telur yang bersih tanpa adanya noda. Perubahan warna kuning pada kuning telur olahan menjadi warna hitam kehijauan disebabkan oleh pemanasan yang terlalu lama sehingga membentuk Fe dan $\mathrm{S}$ (Ariviani et al., 2019).

Aroma/bau telur asin ayam ras dan telur asin itik adalah berbeda nyata artinya telur asin ayam lebih disukai dari pada telur asin itik dari segi aroma/bau (Engelen, 2017). Hal ini kemungkinan disebabkan bau amis pada telur itik masih berbau amis, dikarenakan pemeraman telur itik hanya 9 hari saja. Telur itik dengan pemeraman 20 hari dapat mengurangi bau amis yg terdapat pada telur, semakin lama telur diperam pada adonan garam dan batu bata maka bau amis pada telur asin dapat berkurang (Qomaruddin \& Afandi, 2017).

Rasa telur asin ayam lebih disukai dari pada telur asin itik. Hal ini disebabkan karena telur asin ayam kadar airnya terendah sehingga telur memiliki cita rasa yang lebih enak dan rasa masir atau berpasir kuning telur yang semakin meningkat (Novia et al., 2018). Rasa masir dari kuning telur dipengaruhi oleh besaran minyak yang keluar, kekuatan gel dari kunig telur dan diameter granula kuning telur. Semakin tinggi nilai ketiga kriteria mutu tersebut, rasa masir kuning telur yang dihasilkan semakin tinggi. Lemak dalam telur berfungsi meningkatkan cita rasa. Kemudian hasil penelitian Zulaekah dan Widyaningsih (2005) bahwa ekstrak teh yang digunakan untuk merendam telur asin dapat memperbaiki cita rasa dari telur asin rebus (Ariviani et al., 2019).

Tekstur telur asin ayam ras dan telur asin itik adalah berbeda nyata artinya telur asin ayam lebih disukai dari pada telur asin itik dari segi tekstur (Faridah, 2017). Hal ini disebabkan karena tekstur telur asin itik yang agak lunak karena pengaruh kadar air yang tinggi. Selain itu disebabkan karena pada telur asin itik memiliki kadar air yang tinggi sehingga konversi padatan (lemak) semakin menurun dalam telur, sehingga menyebabkan menurunnya cita rasa telur asin itik. Bentuk suatu bahan ataupun produk akan menentukan tekstur dari bahan-bahan atau produk tersebut. Seimbangnya bentuk dengan padatan yang terkandung bahan atau produk akan menyebabkan tekstur bahan atau produk menjadih lebih baik (Qomaruddin \& Afandi, 2017). 

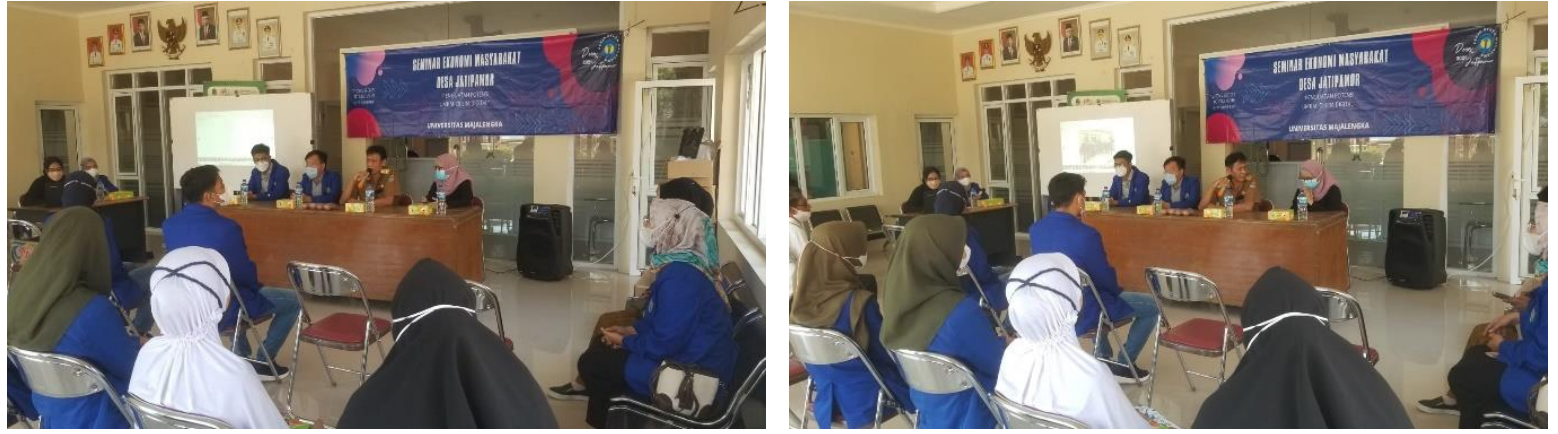

Gambar 1. Sambutan Kepala Desa Jatipamor
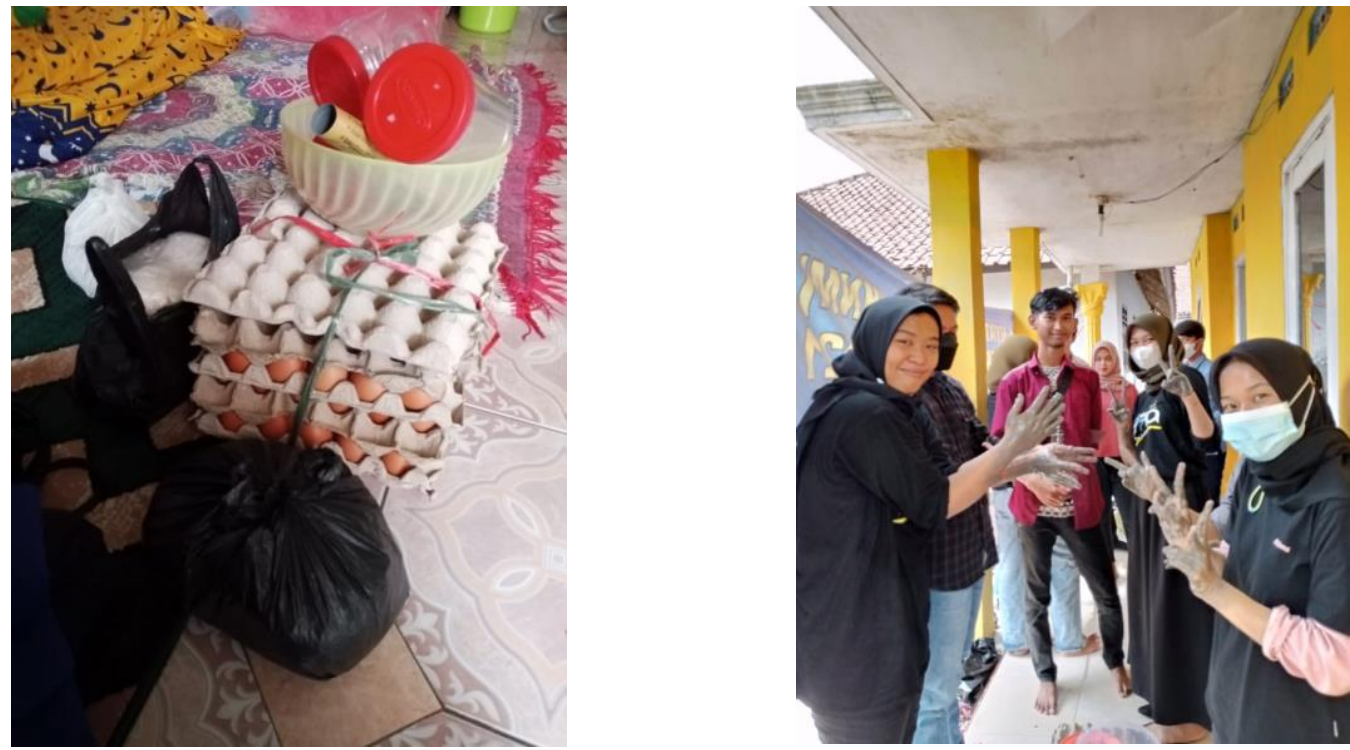

Gambar 2. Alat dan Bahan serta Peserta Penyuluhan
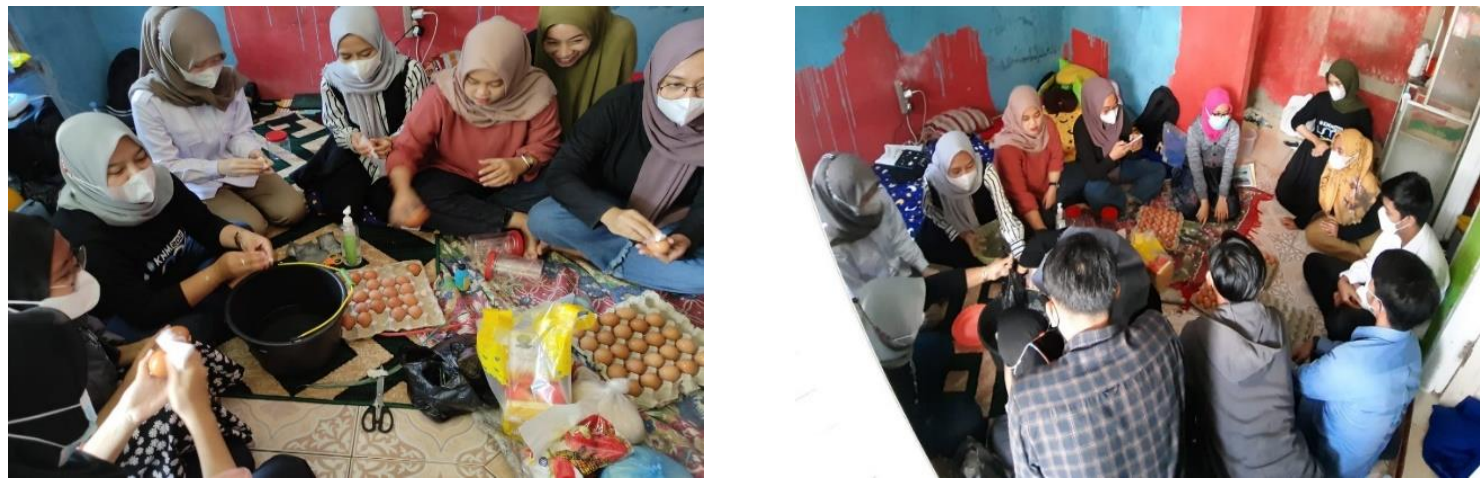

Gambar 3. Membersihkan, Mengampelas, dan Mendesinfeksi Telur Ayam Ras 

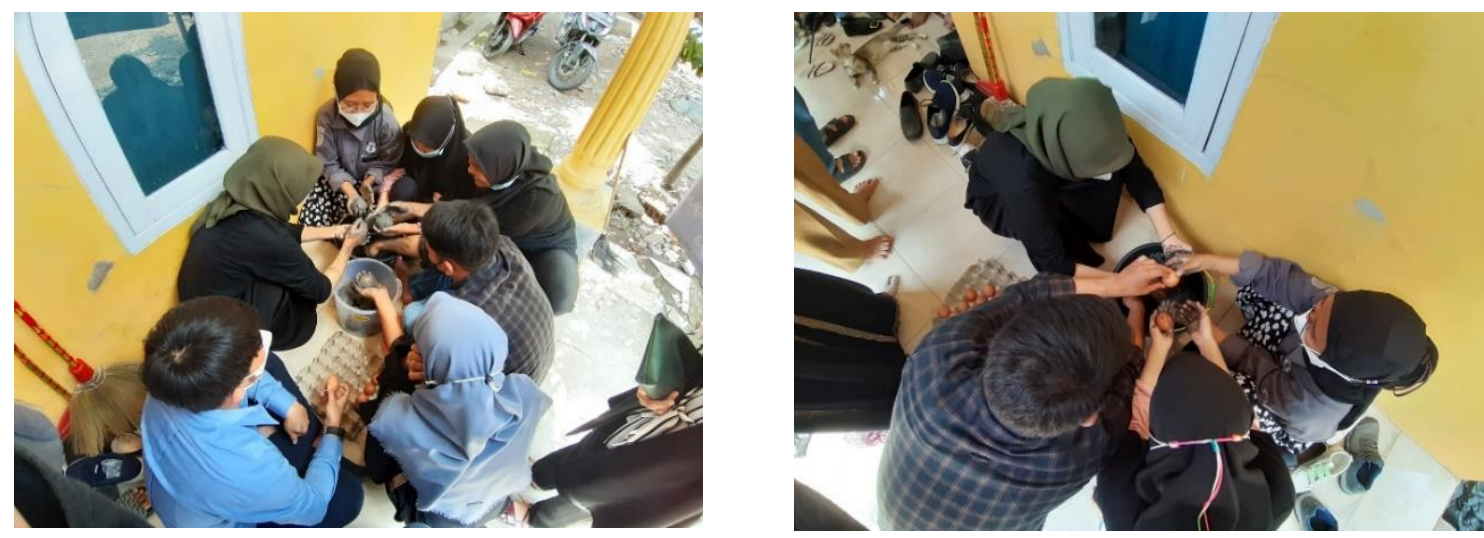

Gambar 4. Proses Pembalutan Telur Ayam Ras dengan Media Abu Gosok
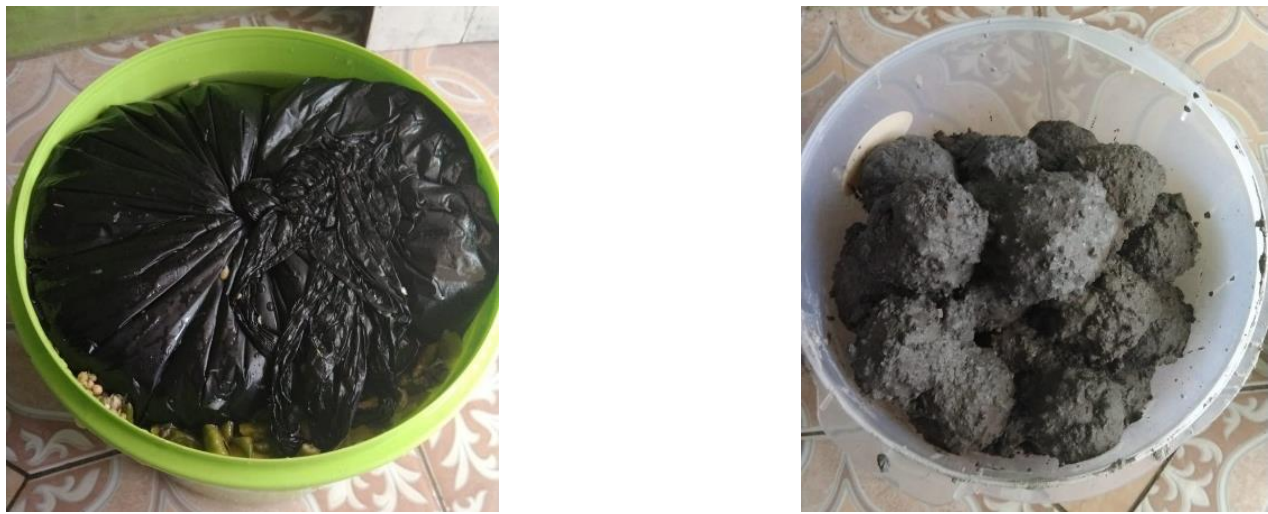

Gambar 5. Proses Penggaraman Telur Ayam Ras Menggunakan Air dan Abu Gosok
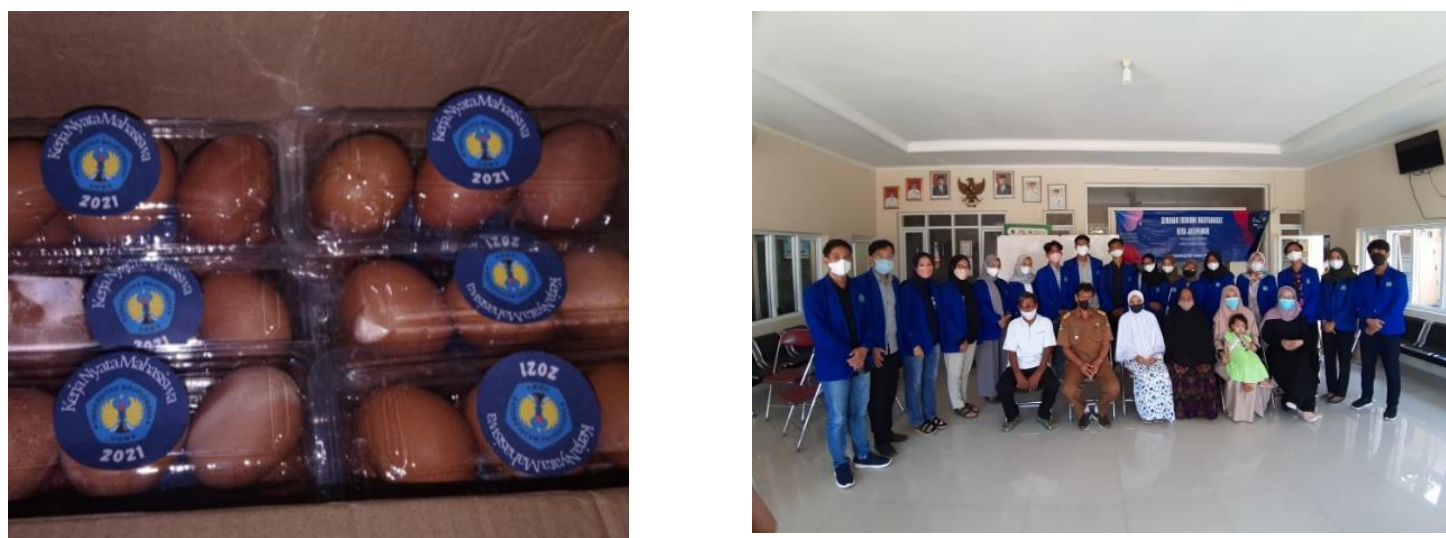

Gambar 6. Telur Asin Ayam Ras dan Peserta Penyuluhan

2. Evaluasi Pengetahuan Peserta

Evaluasi Pengetahuan Peserta Test awal (Pre-Test) dilakukan sebelum kegiatan penyuluhan yang dilaksanakan 7 hari sebelum pelaksanaan penyuluhan. Adapun tujuan pelaksanaan Test awal (Pre- Test) adalah untuk mengetahui tingkat pengetahuan masyarakat dalam diversifikasi pengolahan telur ayam ras dengan metode penggaraman sebagai upaya untuk meningkatkan gizi dan penguatan ekonomi masyarakat. Jumlah responden dalam tes awal (Pre-Test) adalah 25 orang dengan jumlah pernyataan sebanyak 20 pertanyaan. 
Test akhir (Pre-Test) dilakukan setelah kegiatan penyuluhan hal ini dilakukan untuk mengetahui pengetahuan masyarakat dalam diversifikasi pengolahan telur ayam ras dengan metode penggaraman sebagai upaya untuk meningkatkan gizi dan penguatan ekonomi masyarakat. Dalam pelaksanaan evaluasi terdapat 25 orang dengan jumlah pernyataan sebanyak 20 pertanyaan. Nilai hasil evaluasi saat Pre_Test adalah 1062. sedangkan nilai Post-Test mencapai 1258, sehingga terjadi peningkatan pengetahuan peternak setelah dilaksanakan penyuluhan sebesar 196.

3. Monitoring dan Evaluasi

Monitoring dan evaluasi dilakukan secara berkala pada setiap proses kegiatan. Pada saat monitoring diuraikan tentang proses yang terjadi serta kegagalan dan hambatan yang terjadi disebabkan oleh berbagai faktor. Berbagai solusi dan pencegahan kegagalan didiskusikan dengan para peserta penyuluhan.

4. Persepsi Peserta

Setelah mengikuti kegiatan ini peserta pelatihan yang terdiri atas kader PKK, UMKM, dan masyarakat Desa Jatipamor menjadi memiliki keterampilan dalam diversifikasi pengolahan telur ayam ras dengan metode penggaraman sebagai upaya untuk meningkatkan gizi dan penguatan ekonomi masyarakat. Berdasarkan adanya kegiatan ini peserta penyuluhan mempraktekan hasil pengetahuan dan keterampilannya dalam keluarga, sehingga ada telur asin ayam ras sebagai variasi menu pada saat mereka makan. Masyarakat Desa Jatipamor menjadi lebih sehat, kegiatan UMKM nya lebih aktif, dan kondisi ekonominya semakin kuat.

\section{Kesimpulan}

Mitra mendapatkan keterampilan dalam diversifikasi pengolahan telur ayam ras dengan metode penggaraman sebagai upaya untuk meningkatkan gizi dan penguatan ekonomi masyarakat. Telur asin ayam ras dimanfaatkan dalam variasi menu makanan sehari-hari untuk menjaga Kesehatan masyarakat dan dijual sebagai usaha kecil dan menengah untuk menambah penghasilan sehingga tercipta penguatan ekonomi masyarakat saat pandemic dan masa adaptasi kebiasaan baru.

\section{Daftar Pustaka}

Ariviani, S., Fauza, G., \& Ishartani, D. (2019). Peningkatan Kualitas dan Umur Simpan Telur Asin di Industri Rumah Tangga Telur Asin melalui Inovasi Proses Produksi. Prosiding Konferensi Nasional Pengabdian Kepada Masyarakat Dan Corporate Social Responsibility (PKM-CSR). https://doi.org/10.37695/pkmcsr.v2i0.584

Asiah, N. (2021). Prediksi Umur Simpan Dan Nilai Penurunan Mutu Telur Asin Presto Pada Penyimpanan Suhu Rendah. Jurnal Teknologi Pangan Dan Kesehatan (The Journal of Food Technology and Health). https://doi.org/10.36441/jtepakes.v1i2.185

Bandrang, T. N. (2017). Analisis Permintaan Telur Ayam Ras (Suatu Kasus di Kecamatan Seruyan Hilir Kabupaten Kuala Pembuang Kalimantan Tengah). MIMBAR AGRIBISNIS: Jurnal Pemikiran Masyarakat I/miah Berwawasan Agribisnis. https://doi.org/10.25157/ma.v1i1.32

Bao, X., Song, Y., Li, T., Zhang, S., Huang, L., Zhang, S., Cao, J., Liu, X., \& Zhang, J. (2021). Comparative transcriptome profiling of ovary tissue between black muscovy duck and white muscovy duck with high- and low-egg production. Genes. https://doi.org/10.3390/genes12010057

Budiman, C., \& Rukmiasih. (2007). Karakteristik Putih Telur Itik Tegal. Makalah Seminar Nasional Teknologi Peternakan Dan Veteriner.

Engelen, A. (2017). Analisis sensori dan warna pada pembuatan telur asin dengan cara basah. Jurnal Technopreneur. 
Faridah, A. (2017). PENGARUH PENAMBAHAN BAWANG PUTIH TERHADAP KUALITAS TELUR ASIN. JURNAL PENDIDIKAN DAN KELUARGA. https://doi.org/10.24036/jpk/vol9-iss1/41

Jazil, N., Hintono, A., \& Mulyani, S. (2013). Penurunan Kualitas Telur Ayam Ras dengan Intensitas Warna Coklat Kerabang Berbeda Selama Penyimpanan. Jurnal Aplikasi Teknologi Pangan.

Kunaifi, M. A., Wirapartha, \& Wijayana, I. K. A. (2019). Pengaruh penyimpanan selama 14 hari pada suhu kamar terhadap kualitas eksternal dan internal telur itik di daerah jimbaran. Journal of Tropical Animal Science.

Novia, D., Juliyarsi, I., \& Melia, S. (2018). Perbaikan Mutu dan Produksi Telur Asin pada Kelompok Usaha Telur Asin di Sicincin, Kabupaten Padang Pariaman. LOGISTA - Jurnal IImiah Pengabdian Kepada Masyarakat. https://doi.org/10.25077/logista.2.1.1-14.2018

Putri, M. F. (2019). Telur Asin Sehat Rendah Lemak Tinggi Protein Dengan Metode Perendaman Jahe Dan Kayu Secang. JKKP (Jurnal Kesejahteraan Keluarga Dan Pendidikan). https://doi.org/10.21009/jkkp.062.03

Qomaruddin, M., \& Afandi, H. (2017). Tingkat Kesukaan Konsumen Terhadap Telur Asin Ayam Ras dan Telur Asin Itik Di Kecamatan Kembangbahu, Kabupaten Lamongan. Jurnal Ternak. https://doi.org/10.30736/ternak.v8i2.17

Qonita, R. A., Parnato, N. H. Ri., \& Riptani, E. W. (2019). Prospek Penggunaan Abu dari Limbah Pembakaran Batu Bata dalam Usaha Pembuatan Telur Asin. Jurnal DIANMAS.

Ramli, I., \& Wahab, N. (2020). Teknologi Pembuatan Telur Asin Dengan Penerapan Metode Tekanan Osmotik. ILTEK: Jurnal Teknologi. https://doi.org/10.47398/iltek.v15i2.516

Suci, D. margi, Zahera, R., Sari, M., \& Hermana, W. (2020). PenggunaanTepung Kulit Pisang dalam Ransum terhadap Kadar Kolesterol, Vitamin A, Profil Asam Lemak Kuning Telur Ayam Arab. Jurnal IImu Nutrisi Dan Teknologi Pakan. https://doi.org/10.29244/jintp.v18i1.30846 